\title{
Штефан Ланг
}

\section{ФІХТЕВА ПРОГРАМА ІСТОРІЇ ПЕРФОРМАТИВНОЇ САМОСВІДОМОСТІ ${ }^{1}$}

Ідеалістичні системи Йогана Готліба Фіхте та Фридриха Вільгельма Йозефа Шелінга біля 1800 року значною мірою зазнали впливу теоретичної програми, яку Фіхте розвиває в практичній частині «Засади всього вчення про науку» (1794/95) [Fichte, 1997: S. 141]. Це програма iсторії самосвідомості. ${ }^{2}$ У рамках цієї теоретичної програми Фіхте розвиває теорію поняття Я в «Спробі нового викладу вчення про науку», яку можна означити як перформативну теорію самосвідомості, а програму історії самосвідомості розширює в такий спосіб до історії перформативної самосвiдомості [Fichte, 1970a, 1970b, 1970c]. Отож розвиток програми історії самосвідомості та розвиток перформативної теорії суб'єктивності можна зарахувати до центральних постановок завдань та інноваційних досягнень Йогана Готліба Фіхте біля 1800 року. Далі ми ідентифікуємо посутні ознаки цієї теоретичної програми та увиразнимо Фіхтеву перформативну теорію поняття $Я$ в «Спробі нового викладу вчення про науку» $3^{3}$.

\section{1. Фіхтева програма історї самосвідомості}

У 5 «Засади всього вчення про науку» Фіхте через генетичний доказ розвиває програму історії самосвідомості [Fichte, 1997: S. 188ff]. Це програма діє-теоретичного (handlungstheoretischen) дослідження людської суб'єктивності, якій властиво

(C) I. Пасічник, I. Іващенко, переклад, 2014

${ }^{1}$ Переклад 3 німецької Ігоря Пасічника за виданням Lang S. Fichtes Programm einer Geschichte performativen Selbstbewusstseins. In: System der Vernunft: Kant und der deutsche Idealismus. Hrsg. v. Christian Danz und Jürgen Stolzenberg, Hamburg, Meiner: 2011, S. 29-43. Наукова редакція перекладу та переклад цитат з англійської Івана Іващенка. - Прим. peд. Sententiae.

2 Означення історія самосвідомості застосовуе Шелінг у «Системі трансцендентального ідеалізму». Фіхте в «Засаді всього вчення про науку» (1794/95) означує своє дослідження як прагматичну історію самосвідомості. [Див. Schelling, 1992: S. 67; Fichte, 1997: S. 141].

3 До цього часу в дослідженнях ідеалізму порівняно небагато філософів переймалися програмою iсторії самосвідомості. Перше систематичне дослідження, передусім щодо раннього вчення про науку Фіхте, представив у 1970-х роках Ульрих Клесгес. У середині 1990-х років Клаус Дюзинг уперше спробував переформулювати цю теоретичну програму. Дюзинг розвиває тісно орієнтовану на ідеалістичні проекти історії самосвідомості теорію людської суб'єктивності, яка містить типологію моделей самостосунку. Юртен Штольиенберт дослідив розвиток Фіхтевої програми історії самосвідомості, починаючи з нереалізованих підходів Карла Леонгарда Райнгольда, а також реалізацію цієї програми в «Системі трансцендентального ідеалізму» Шелінга та «Феноменології духу» Гегеля. Див. [Claesges, 1974; Düsing, 1995, 1997; Stolzenberg, 2003, 2009]. 
те, що перспектива першої особи є спрямувальною парадигмою дослідження. Дослідження питання, як суб'єкт самого дослідження розвиває самосвідомість, визначає розвиток теорії в Фіхтевій історії самосвідомості. «Я», так пояснює Фіхте в генетичному доказі $\S 5$ «Засади всього вчення про науку», «має не [...] покладати себе самого для якогось розуму поза собою, а має покладати себе для себе самого» [Fichte, 1997: S. 191, курсив відповідає оригіналу].

3 огляду на перспективу першої особи в історії самосвідомості підлягає тематизації відмінність між перспективою суб'єкта дослідження та перспективою читача/теоретика. Читач/теоретик отримує інформацію про поступовання дослідження та конституцію суб'єктивності, яка залишається прихованою для суб'єкта дослідження. До того ж на основі Фіхтевих пояснень та вступів до дослідження читач/теоретик орудує поняттями про суб'єктивність, про які розвиток теорії засвідчує, як суб'єкт дослідження розвиває ці поняття ${ }^{4}$.

У Фіхтевому діє-теоретичному дослідженні людської суб’єктивності є ментальні і практичні дії, які уможливлюють самосвідомість, предикати суб'єкта станів свідомості. Це означає, що в історії самосвідомості Фіхте розвиває діє-теоретичну онтологію суб'єкта станів свідомості. У своїх численних публікаціях Фіхте особливо наполегливо звертає увагу читача на цю діє-теоретичну інтерпретацію самості. У «Першому вступі» до «Спроби нового викладу вчення про науку» Фіхте наголошує: «Для ідеалізму розум є чином (Tun), й абсолютно нічим іншим; його навіть не слід називати діяльним, бо цим виразом вказують на дещо наявне, чому властива діяльність» [Fichte, 1966: S. 313f].

Предикати суб'єкта станів свідомості виконують у Фіхтевій програмі icmopiï самосвідомості два завдання. Властивості самості є ментальними та практичними діями, які уможливлюють людську самосвідомість, $a$ водночас становлять необхідні умови людської свідомості. ${ }^{5}$ До умов людської свідомості, які ідентифікують в icmopiї самосвідомості, зараховують, однак, не лише ментальні та практичні дії суб'єкта станів свідомості. Ідентифікації підлягають також умови, що незалежні від суб'єкта, позаяк вони потрібні для пояснення конституції людської свідомості та самосвідомості, як, наприклад, поштовх, тобто витворений суб'єктом зміст.

Особлива риса програми історії самосвідомості полягає в тому, що значення предикатів суб'єкта станів свідомості визначають іманентно в теорії [див. Stolzenberg, 2003, 2009а]. Значення предикатів суб'єкта не запозичують з філософських теорій, як, приміром, 3 Кантової критичної теорії пізнання. Значення предикатів суб'єкта обгрунтовують у розвиткові теорії так, що значення предикатів ідентифікують зі значенням функцій, які виконують предикати в історії самосвідомості [Stolzenberg, 2003, 2009b]. Так, наприклад, порив (Trieb) позначає «прагнення, що продукує себе самого [...] що є встановленим, визначеним, чимось певним» [Fichte, 1997: S. 204] й сприяє, зокрема, поясненню, як можлива дія, означена як прагнення [Ibid.].

Урешті-решт, Фіхтевій програма історії самосвідомості характерно те, що конституція самосвідомості та людської свідомості пояснюють в рамках телеологічної історії розвитку. Це значить, що в історї̈ самосвідомості, в основі якої лежить ви-

${ }^{4}$ Щодо питання, яке значення має розрізнення цих перспектив для розвитку теорії, слід казати про різні ідеалістичні історії самосвідомості. Дослідженням ідеалізму бракує детального систематичного викладу цих розрізнень.

5 Вирази «суб'єкт станів свідомості», «самість» і «суб'єкт» ми вживаємо як синоніми, якщо не зазначено інше. 
значена ціль, розвивають теорію дій самості, які необхідно настають одна за одною. Ціль Фіхтевої історії самосвідомості полягає в поясненні, як суб'єкт дослідження отримує інтенційну свідомість з того поняття суб'єктивності, 3 якого починається теорія.

Отже, сутнісними рисами Фіхтевої програми історії самосвідомості є те, що, поперше, Фіхте розвиває діє-теоретичне дослідження людської самосвідомості і свідомості, в якому, по-друге, парадигмою, що спрямовує дослідження, є перспектива першої особи. Ідентифікуючи дії суб'єкта 3 предикатами суб'єкта станів свідомості, в історії самосвідомості Фіхте розвиває, по-третє, діє-теоретичну онтологію самості. По-четверте, значення предикатів самості визначають в розвитку теорії за допомогою функиії, яку в розвитку теорії виконують предикати. Кінець кінцем, n'ята риса програми історії самосвідомості означає, що в теорії в рамцях телеологічної історії розвитку увиразнюють, як суб'єкт дослідження розвиває свідомість про поняття суб'єктивності, на яке спирається теорія.

Перше вчення про науку, яке повністю розвиває цю теоретичну програму, $\epsilon$ «Учення про науку nova methodo». Незадовго до розвитку «Учення про науку nova methodo» Фіхте застосовує програму історії самосвідомості вже в «Засаді природного права згідно 3 принципами вчення про науку» ${ }^{6}$. Отож «Засада природного права» містить перше застосування програми історї самосвідомості. У дослідженнях ідеалізму раніше це детально не вивчали.

\section{2. Виклад програми історії самосвідомості в «Засаді природного права»}

Фредерік Нойгаузер у статті «Дієвість раціонального буття» [Neuhouser, 2001] узагальнив постановку завдань «Засади природного права» таким чином:

1) визначити зміст поняття права,

2) показати, що поняття права є необхідною ідеєю розуму, та

3) показати, як це поняття права можна застосовувати в світі досвіду [Ibid., S. 39; див. також Fichte, 1966: S. 319f].

Як справедливо зазначає Нойгаузер, Фіхте вирішує ці завдання, ідентифікуючи поняття права як необхідну умову самосвідомості: «The key to articulating Fichte's strategy for achieving these goals lies in his understandig of what "deduction" consists in [...] "deduction" in the present context refers to a species of transzendental argument. According to his view, philosophy proves the rational necessity of the concept of right by showing it to be a necessary condition of the possibility of self-consciousness» [Neuhouser, 2001: S. 39] ${ }^{7}$ Під самосвідомістю в «Засаді природного права» Фіхте розуміє свідомість, що може розвивати поняття цілі та спонтанно й «самовизначено» діяти ${ }^{8}$.

6 Перша частина «Засади природного права» вийшла друком навесні 1796 р. Першу лекцію «Учення про науку nova methodo» Фіхте прочитав у зимовому семестрі 1796/97 pp. А втім, можливо, що вже під час розвитку «Засади природного права» Фіхте почав розвивати «Учення про науку nova methodo». Див. також зауваження видавця «Повного видання творів» Фіхте у [Fichte, 1998a: S. 8f].

7 «Ключ до увиразнення Фіхтевої стратегії досягнення цих цілей полягає в його розумінні суті «дедукції» [...] «дедукція» в цьому контексті стосується різновиду трансцендентального аргументу. На думку Фіхте, філософія доводить раціональну необхідність поняття права, увиразнюючи, що воно становить необхідну умову можливості самосвідомості».

8 «У понятті свободи міститься передусім лише здатність через абсолютну спонтанність розробляти поняття про нашу можливу дієвість; й лише цю здатність розумні істоти приписують 
Фіхте наголошує, що під час ідентифікації необхідних умов самосвідомості перспектива першої особи є парадигмою, що скеровує дослідження. У «Засаді природного права» Фіхте показує, як досліджений суб'єкт сам розвиває свідомість себе самого: «Тепер для цього рефлексувального Я має бути об'єктом інше Я, тобто це Я має бути об'єктом для себе самого. Як це можливо? про це тут йтиметься» [Fichte, 1966: S. 333] $]^{9}$. Суб'єкт станів свідомості є, отже, не лише вихідним пунктом дослідження, а й мета «дедукції поняття права» полягає в тому, щоб показати, як суб'єкт розвиває самосвідомість. У «Засаді природного права» Фіхте пояснює конституцію самосвідомості, ідентифікуючи дії суб'єкта, які необхідно йдуть одна за одною, та інтерсуб'єктивні умови людської самосвідомості [див. Siep, 1981; Honneth, 2001]. До інтерсуб'єктивних умов можна зарахувати, наприклад, взаємне визнання суб'єктів як розумних істот, які можуть покладати цілі та справджувати їх у світі досвіду [див. Fichte, 1966: S. 350f; Siep, 1992: S. 32]. Та основу дослідження становить ідентифікація ментальних і практичних дій самості, які Фіхте ідентифікує з предикатами суб'єкта: «Розумна істота $\epsilon$ винятково тому, що вона покладає себе як сущу, тобто тому, що вона усвідомлює саму себе. [...] як наслідок, це робить необхідним усе те, що властиво покладанню себе через себе самого, й міститься в полі увиразненої через це покладання дії [...] сама розумна істота є лише своїм діянням» [Fichte, 1966: S. 314]. Значення предикатів суб'єкта Фіхте визначає в «Засаді природного права», ідентифікуючи їх як необхідні умови самосвідомості. Іншими словами, значення предикатів суб'єкта визначають у розвитку теорії за допомогою функції, яку виконують предикати в поясненні конституції самосвідомості $^{10}$. Так, наприклад, властивість суб'єкта, яку Фіхте в $\S 1$ «Засади природного права» ідентифікує та означує як діяльність у світогляді, виконує функцію пояснення, як можлива саморефлексія суб'єкта [Ibid., S. 329f].

Отже, у «Засаді природного права» Фіхте застосовує програму icmopii самосвідомості, щоби визначити поняття права та вказати на нього як на поняття розуму. «Засада природного права» розвиває діє-теоретичне дослідження людської самосвідомості, в якому перспектива першої особи являє собою провідну нитку дослідження. У згоді з програмою історії самосвідомості підлягають ідентифікації

одна одній з необхідністю» [Fichte, 1966: S. 319]. «Суб’єкт може не вважати себе змушеним до справжньої дії, адже тоді він не був би ні вільним, ні Я. [...] Отже, як і в якому сенсі він призначений до дієвості (Wirksamkeit), щоби подибувати себе як об’єкта? Лише тією мірою, що він виявляє себе як щось, що могло б тут діяти, діяти на вимогу, але також може і не робити цього» [Ibid., S. 343].

Це - інтенційна екстерналістська практична самосвідомість, тобто свідомість власної практичної спонтанності, яку уможливлює зовнішня причина й яка містить свідомість цього зовнішнього впливу : «Питання було: як може суб’єкт виявити себе як об'єкт? [...] Він міг, щоб виявити себе як об'єкт (своєї рефлексії), не виявляти себе як такого, що визначає себе до самодіяльності $[\ldots]$ а як визначеного до неї через зовнішній поштовх, який все-таки має лишити йому повну свободу до самовизначення» [Ibid.].

${ }^{9}$ Див. також [Neuhouser, 2001: S. 41]: «Grundlage des Naturrechts [...] inquires into the conditions under which a finite, rational subject can achieve consciousness of itself as such, and its aim is to show that the concept of right constitutes one of those conditions» («Засада природного права [...] досліджує умови, за яких скінченний, раціональний суб’єкт може досягнути свідомості себе як такого, а їі мета в тім, щоби унаочнити, що поняття права конституює одну з цих умов»).

${ }^{10}$ Див. [Fichte, 1966: S. 315]: «Це слово [тобто поняття] має тут означати лише те, що тут описане; міг би читач при тому раніше думати те саме, чи ні. Я не посилаюся на вже наявне в нього поняття, а хочу лише розвинути та визначити таке поняття в його духові». 
дії, що необхідно йдуть одна за одною, які уможливлюють інтенційну самосвідомість і становлять предикати суб'єкта станів свідомості. I то значення предикатів обгрунтовують іманентно в теорї в такий спосіб, що їхнє значення ідентифікують 3 функцією, яку виконують предикати в розвитку теорії. Урешті-решт, згідно з програмою історії самосвідомості можна показати ціль дослідження: що уможливлює розвиток суб'єктом дослідження свідомості про поняття суб'єктивності, 3 якого починається дослідження.

Проте «Засада природного права» не є викладом учення про науку, тобто викладом фундаменту філософської системи Фіхте, натомість вона містить філософське обгрунтування вчення про природу. Отже, історія самосвідомості, яку Фіхте розвиває в «Засаді природного права», відрізняється в багатьох аспектах від викладу icmopiї самосвідомості в «Ученні про науку nova methodo» ${ }^{11}$. Зокрема, треба згадати про те, що в «Засаді природного права» вихідним пунктом дослідження є скінченний суб'єкт, а в «Ученні про науку nova methodo»-абсолютний суб'єкт.

Незадовго після публікації «Засади природного права» Фіхте у «Спробі нового викладу вчення про науку» розширює програму історії самосвідомості до історії перформативної самосвідомості. У «Спробі нового викладу вчення про науку» вихідний пункт дослідження утворює теорія поняття $Я$, яка на основі їі узгодження із ознаками перформативних висловлювань може бути означена як перформативна теорія поняття Я.

3. Фіхтева перформативна теорія поняття Я $у$ «Спробі нового викладу вчення про науку»

Те, що Фіхтева теорія поняття Я являє собою перформативну теорію, можна збагнути, порівнявши Фіхтеву теорію поняття $Я$ з ознаками перформативних висловлювань.

a) Перформативні висловлювання

В аналітичній філософії перформативними вважають ті висловлювання, в яких поряд із висловлюванням виконують дію [див. Austin, 2002, 1990; а також. Krämer, 2001: S. 138ff]. Приміром, висловом «Я охрещую тебе іменем ху» хрестять. Утім, перформативними висловлюваннями є не лише вислови, які являють собою дії, натомість перформативне висловлювання також має семантичний зміст, який тематизує дію, яку виконують завдяки перформативним висловлюванням. Так, зміст вислову «Я оголошую вас чоловіком та жінкою» тематизує дію, яку виконують перформативним висловлюванням [див., наприклад, Wirth, 2002: S. 10f]. Як правило, перформативні висловлювання передбачають, що особа, яка робить перформативний вислів, усвідомлює перформативну дію. Хоча можливі випадки, в яких особа робить перформативний вислів й не усвідомлює цього. Це, наприклад, випадок, коли особа робить перформативний вислів мовою, якої не розуміє. Але, як правило, особа

11 у фіхтезнавстві досі бракує систематичного дослідження методичних та аргументативнологічних відмінностей Фіхтевого викладу історій самосвідомості. Окрім того в дослідженнях ідеалізму немає жодного детального систематичного дослідження відмінностей між історіями самосвідомості Фіхте, Шелінга та Гегеля. Вказівки на подібності та відмінності історій самосвідомості в класичній німецькій філософії містяться у [Claesges, 1974; Stolzenberg, 2009b, 2003; Düsing, 1993]. Див. також [Richli, 1994]. 
розуміє значення вислову, який вона робить, а цим самим усвідомлює дію, яку вона виконує. Отже, перформативні висловлювання є, як правило, істинними висловами: особа, яка робить перформативний вислів, виконує дію та усвідомлює i $^{12}$. Проте перформативний вислів може не вдатися, якщо не дотримано певних умов. Приміром, не вдається перформативний вислів: «Я дарую це тобі», якщо подарунок не вручається [Austin, 2002: S. 31]. Щоби перформативний вислів мав сенс, треба, отже, виконувати додаткові дії.

b) Фіхтева теорія поняття Я у «Спробі нового викладу вчення про науку»

У «Спробі нового викладу вчення про науку» Фіхте розвиває діє-теоретичну інтерпретацію значення поняття «Я» ${ }^{13}$. Поняття «Я» не позначає часовопросторового індивіда. Фіхте пояснює, що поняття «Я»є поняттям «мислення, що повертається до себе» чи «діяння самого Я на себе» [Fichte, 1970b: S. 272] ${ }^{14}$. Іншими словами, поняття «Я»є поняттям суб'єкта, який спонтанно витворює неінтенційну чи нерефлексійну самосвідомість.

У «Спробі нового викладу вчення про науку» Фіхте настирливо вказує читачеві на те, що поняття «Я» становить результат «мислення, що повертається до себе», тобто результат принципу вчення про науку [Ibid., S. 276]. Наприклад: «Спробуймо краще увиразнити суть: коли я тобі сказав - мисли себе, а ти зрозумів останнє слово, то в акті самого розуміння ти виконав діяльність, щьо повертається до себе, $і$ завдяки якій постає думка про Я» [Ibid., S. 280]. Проте самосвідомість, яку витворює «діяльність, що повертається до себе», можлива лише тоді, коли суб'єкт витворює поняття «Я» ${ }^{15}$ : «Отже, з поняттям Я було необхідно об 'єднане його споглядання [тобто «діяльність, що повертається до себе»] і свідомість Я була б без нього неможливою. Адже лише поняття завериує та містить свідомість» [Fichte, 1979: S. 347].

Фіхте наголошує, що конституція самосвідомості водночас становить й конституцію суб'єкта станів свідомості ${ }^{16}$. Суб'єкт станів свідомості постає в

12 Суть дебатів щодо перформативних висловлювань полягає в дослідженні питання, являють собою перформативні висловлювання істинні вислови чи ні. Тоді як дескриптивісти на кшталт Кента Баха припускають, що має сенс означувати перформативні висловлювання як істинні вислови, недесриптивісти на кшталт Джона Остина це припущення відхиляють. У даному дослідженні представлена позиція дескриптивістів (див. [Bach, 1975]), тому перформативні висловлювання позначуються також як перформативні вислови.

13 У «Спробі нового викладу вчення про науку» Фіхте не розвиває систематичний аналізу значення виразу «я». Коли надалі тематизується Фіхтеве поняття Я, то поняття «Я», щоб відмежувати його від семантичних досліджень виразу «Я», пишеться з великої літери.

${ }^{14}$ Див. також [Fichte, 1970b: S. 273]: «Отож ти, мабуть, залучатимеш до поняття Я щось, що я до нього не залучив, приміром, поняття твоєї індивідуальності, тому що індивідуальність також позначають за допомогою того мовного знаку [Я]. Відтепер ти звільнений від цього: лише те, що постає завдяки поверненню твого мислення до себе самого, є Я, про яке я тут кажу».

15 У ході дослідження Фіхте показує, що ця форма саморефлексії не є випадком інтенційної самосвідомості. На цій підставі Фіхте означує цю неінтенційну дію в «Новому опрацюванні вчення про науку» (1800) як «рефлекс свідомості». Фіхте експліцитно пояснює, що він відрізняється від рефлексії [Fichte, 1979: S. 347]. На цій підставі означення «саморефлексія» $є$ в даному зв'язку прийнятним.

16 «Ця безпосередня свідомість є щойно описаним спогляданням Я. Я необхідно покладає себе самого в иььому спогляданні [...] Це покладання себе самого не має витворювати існування Я, як наявної незалежно від свідомості речі в собі [...] Це споглядання так само не припускає незалежного від свідомості існування Я як (споглядальної) речі» [Ibid., S. 277]. 
зв'язку з конституцією поняття «Я». Отже, Фіхтевій теорії поняття Я властива характерна для перформативних висловів ознака, що з витворенням семантичного змісту постає феномен. У зв’язку з витворенням поняття «Я» постає самосвідомий суб' скm $^{17}$. Позаяк поняття «Я» містить інформацію, що діяльність суб'єкта повертається до себе самої, Фіхте розвиває теорію конституції поняттєвої самосвідомості, в основі якої лежить стосунок дії суб'єкта та поняттєвого змісту, який постає у випадку перформативних висловів. У перформативних висловах зміст перформативного вислову тематизує дію, яку виконують одночасно з перформативним висловом. Саме цей стосунок характерний Фіхтевому поясненню конституції самосвідомості: витворюване суб’єктом поняття «Я» містить інформацію, що діяльність «повертається до себе». Фіхте водночас наголошує, що поняття «Я» витворюється через «діяльність, що повертається до себе» ${ }^{18}$. Тому як і у випадку перформативних висловів Фіхтевого пояснення конституції поняття «Я» також стосується те, що суб'єкт схоплює істинну думку, щойно витворює поняття «Я». Витворюючи поняття «Я», суб'єкт усвідомлює себе як суб’єкта, чия діяльність повертається до себе. Кінець кінцем, Фіхтева теорія поняття $Я$ узгоджується із перформативними висловами також тому, що треба виконати певні передумови, щоби уможливити конституцію поняття «Я». Так само, як і у випадку перформативного вислову «я дарую це тобі» потрібні додаткові дії, щоби вислів був перформативним висловом, так і суб'єкт має виконувати додаткові дії, щоб була можливою конституція поняття «Я». Так, у «Спробі нового викладу вчення про науку» Фіхте пояснює, що вчення про науку реконструює конституцію людської свідомості таким чином, що спочатку витворюють поняття «Я», а в теорії ідентифікують дії, що потрібні для можливості конституції поняття «Я» 19 .

${ }^{17}$ Це не означає, що завжди, коли наявний суб’єкт, він витворює поняття «Я». Навпаки, вислів Фіхте стосується конституції суб'єктивності в зв'язку з поняттєво-артикульованою самосвідомістю. Від цієї поняттєво-артикульованої самосвідомості відрізняється інтелектуальне споглядання чи «діяльність, що повертається до себе». Інтелектуальне споглядання наявне, отже, не лише в зв'язку з конституцією поняття «Я», а також у випадках тілесної самосвідомості: «Але, мабуть, кожен може виявити на підставі визнаного ним самим досвіду, що це інтелектуальне споглядання виринає в кожному моменті його свідомості. Я не можу зробити жодного кроку, поворухнути рукою чи ногою без інтелектуального споглядання моєї самосвідомості у цих діях; лише через це споглядання я знаю, що я роблю це; лише через нього я розрізняю свою дію й себе в ній від даного об'єкта дії» [Fichte, 1970c: S. 217]. Отже, конституція суб'єкта має місце не лише у випадку, коли витворюється поняття «Я». Але суб'єкт все-таки завжди постає також у зв'язку з витворенням цього поняття [Fichte, 1970b: S. 273f., 277].

18 «Поняття завжди є діяльністю самого споглядання, яке, втім, схоплене не як рухливість, а як спокій та визначеність. Так само стоять справи із поняттям Я» [Ibid., S. 280]. Перед штудіюванням вчення про науку читач, звісно, не усвідомлює того, як діяльність, що повертається до себе, передує собі, тобто що йдеться про неінтенційну самосвідомість.

19 «Цей ідеалізм спирається на єдиний принцип розуму, який він виявляє безпосередньо в свідомості. При цьому він чинить так. Він закликає слухача вільно мислити певне визначене поняття [цим поняттям є «Я»]; якщо він це робитиме, то виявить, що змушений чинити в певний спосіб. [...] Він [ідеалізм] показує, щзо встановлене спочатку як приниип [...] неможливе без того, щчоб водночас не відбувалося щзе й дещо інше, а це інше неможливе без того, щэоб водночас не відбулося дещо третє; і так буде до повного вичерпання умови вказаного спочатку, й воно, згідно зі своєю можливістю, не стане повністю зрозумілим. [...] Якщо передумова ідеалізму вірна, [...] тоді, як останній результат, як сукупність усіх умов спочатку встановленого, має постати система всіх необхідних уявлень чи весь досвід» [Fichte, 1970a: S. $204 \mathrm{ff}]$. Див. також [Fichte, 1978b: S. 31f., 40; 1982: S. 32, 34, 43]. 
Хоча Фіхте не здійснює семантичного дослідження вислову «я», але в зв'язку зі своєю теорією поняття $Я$ він розвиває перформативне пояснення конституції Ясвідомості $^{20}$. Як і у випадку перформативних висловів, у конституції поняття «Я» суб'єкт виконує дію, яка породжує феномен і витворює поняттєвий зміст, який тематизує цю дію. У згоді з перформативними висловами особа, яка витворює це поняття, усвідомлює дію, яку вона виконує, і ця свідомість містить істинну думку. Урешті-решт, конституція поняття «Я», можлива лише тоді, коли виконані певні передумови, тобто коли суб'єкт виконує додаткові дії.

Але «Спробі нового викладу вчення про науку» властиво не лише те, що Фіхте розвиває перформативну теорію Я-свідомості. Позаяк вихідний пункт Фіхтевої реконструкції людської самосвідомості полягає в тому, щоб ідентифікувати умови, які уможливлюють конституцію поняття «Я», то «Спроба нового викладу вчення про науку» містить виклад програми історії самосвідомості, яка передбачає теорію можливості перформативної Я-свідомості. Тому заплановану Фіхте в «Спробі нового викладу вчення про науку», але повністю не видану історію самосвідомості, слід означувати як історію перформативної самосвідомості. Отже, розвиток перформативної теорії людської самосвідомості поряд із розвитком програми iсторії самосвідомості слід зарахувати до центральних завдань та інноваційних досягнень Йогана Готліба Фіхте біля 1800 року.

\section{СПИСОК ЛІТЕРАТУРИ}

Austin (1990): Austin, J.L. «Performative Utterances». In: Austin, J.L. Philosophical Papers. Ed. by J.O. Urmson and G.J. Warnock. Oxford: Oxford UP, 1990, P. 233-252.

Austin (2002): Austin, J.L. Zur Theorie der Sprechakte. Hrsg. v. Eike von Savigny. Stuttgart: Reclam, 2002, $217 \mathrm{~S}$.

Bach (1975): Bach, K. «Performatives are statements too». In: Philosophical Studies, Vol. 28, 1975, P. 229-236.

Claesges (1974): Claesges, U. Geschichte des Selbstbewußtseins. Der Ursprung des spekulativen Problems in Fichtes Wissenschaftslehre von 1794-95. Den Haag: Nijhoff, 1974, (xi) 204 S.

Düsing (1993): Düsing, K. «Hegels "Phänomenologie" und die idealistische Geschichte des Selbstbewußtseins». In: Hegel-Studien: B. 28. Hrsg. v. Friedhelm Nicolin und Otto Poggeler. Bonn: H. Bouvier Verl H. Grundmann, 1993, S. 103-126.

Düsing (1997): Düsing, K. Selbstbewußtseinsmodelle. Moderne Kritiken und systematische Entwürfe zur konkreten Subjektivität. München: W. Fink, 1997, 287 S.

Düsing (1995): Düsing, K. «Strukturmodelle des Selbstbewußtseins. Ein systematischer Entwurf». In: Fichte-Studien, B. 7: Subjektivität. Hrsg. v. K. Hammacher \& R. Schottky \& W.H. Schrader. Amsterdam \& Atlanta: Rodopi, 1995, S. 7-26.

Fichte (1970a): Fichte, J.G. Erste Einleitung. In: Fichte, J.G. Gesamtausgabe der Bayerischen Akademie der Wissenschaften (далі - GA), R. I, B. 4: Werke 1797-1798. Hrsg. v. Reinhard Lauth und Hans Gliwitzky unter Mitwirkung von Richard Schottky. Stuttgart-Bad Cannstatt: Frommann-Holzboog, 1970a, S. 186-208.

Fichte (1978a): Fichte, J.G. GA, R IV, B. 2: Kollegnachschriften 1796-1804. Hrsg. v. Reinhard Lauth und Hans Gliwitzky unter Mitwirkung von Jose Manzana, Erich Fuchs, Kurt Hiller und Peter K. Schneider. Stuttgart-Bad Cannstatt: Frommann-Holzboog, 1978a, XI, 376 S.

Fichte (1997): Fichte, J.G. Grundlage der gesamten Wissenschaftslehre: als Handschrift für seine Zuhörer (1794/95). Hamburg: Meiner, 1997, (xxviii) 258 S.

Fichte (1966): Fichte, J.G. Grundlage des Naturrechts nach Principien der Wissenschaftslehre 1796. In: Fichte, J.G. GA, R. I, B. 3: Werke 1797-1798. Hrsg. v. Reinhard Lauth und Hans

${ }^{20}$ Див. щодо цього [Lang, 2010]. 
Gliwitzky unter Mitwirkung von Richard Schottky. Stuttgart-Bad Cannstatt: FrommannHolzboog, 1966, S. 291-460.

Fichte (1979): Fichte, J.G. Neue Bearbeitung der Wissenschaftslehre. In: Fichte, J.G. GA, R. II, B. 5: Nachgelassene Schriften 1796-1801. Hrsg. v. Reinhard Lauth und Hans Gliwitzky unter Mitwirkung von Erich Fuchs, Kurt Hiller, Walter Schieche, Peter K. Schneider und Manfred Zahn. Stuttgart-Bad Cannstatt: Frommann-Holzboog, 1979, S. 319-402.

Fichte (1970b): Fichte, J.G. Versuch einer neuen Darstellung der Wissenschaftslehre. In: Fichte, J.G. GA, R. I, B. 4..., 1970b, S. 167-185.

Fichte (1978b): Fichte, J.G. Wissenschaftslehre (nova methodo) aus den Jahren 1796-97. In: Fichte, J.G. GA, R. IV, B. 2.., 1978b, S. 1-267.

Fichte (1982): Fichte, J.G. Wissenschaftslehre nova methodo. Kollegnachschrift K. Chr. Fr. Krause. Hrsg. v. Erich Fuchs. Hamburg: Meiner, 1982, (xxx) 270 S.

Fichte (1970c): Fichte, J.G. Zweite Einleitung in die Wissenschaftslehre. In: Fichte, J.G. GA, R. I, B. $4 \ldots, 1970$ c, S. 209-270.

Honneth (2001): Honneth, A. Transzendentale Notwendigkeit und Intersubjektivität. Johann Gottlieb Fichte. Grundlage des Naturrechts. Hrsg. v. Jean-Christophe Merle. Berlin: Akademie Verlag, 2001, S. 63-80.

Krämer (2001): Krämer, S. Sprache, Sprechakt, Kommunikation. Sprachtheoretische Positionen des 20. Jahrhunderts. Frankfurt a. M.: Suhrkamp, 2001, 286 S.

Lang (2010): Lang, S. Die Spontaneität des Selbst. Göttingen: Vandenhoeck \& Ruprecht, 2010, $144 \mathrm{~S}$.

Neuhouser (2001): Neuhouser, F. «The Efficacy of the Rational Being (First Proposition: § 1)». In: Johann Gottlieb Fichte. Grundlage des Naturrechts. Hrsg. v. Jean-Christophe Merle. Berlin: Akademie-Verlag, 2001. S. 39-50.

Richli (1994): Richli, U. «Ich aber fordere Sie auf, absolute Genesis ins Auge zu fassen». In: Realität und absolute Negativität in Fichtes Wissenschaftslehre von 1804 und in Hegels Wissenschaft der Logik. Realität und Gewissheit: Tagung der Internationalen J.-G.-FichteGesellschaft (6.- 9. Oktober 1992) in Rammenau in Zusammenarbeit mit dem Istituto per gli Studi Filosofici (Neapel). Hrsg. v. Helmut Girndt u. Wolfgang Schrader. Amsterdam [u. a.]: Rodopi, 1994, S. 423-434.

Schelling (1992): Schelling, F.W.J. System des transzendentalen Idealismus. Hamburg: Meiner, 1992, (xlvi) $310 \mathrm{~S}$.

Siep (1981): Siep, L. «Methodische und systematische Probleme in Fichtes "Grundlage des Naturrechts"». In: Der transzendentale Gedanke. Die gegenwärtige Darstellung der Philosophie Fichtes. Hrsg. v. Klaus Hammacher. Hamburg: Meiner, 1981, S. 290-306.

Stolzenberg (2003): Stolzenberg, J. «"Geschichte des Selbstbewußtseins”. Reinhold - Fichte Schelling». In: Internationales Jahrbuch des Deutschen Idealismus/International Yearbook of German Idealism: Band 1: Konzepte der Rationalität im Deutschen Idealismus. Hrsg. v. Karl Ameriks u. dems. Berlin-N.Y.: De Gruyter, 2003, S. 93-113.

Stolzenberg (2009a): Stolzenberg, J. Fichte heute. Information Philosophie. 27 August 2009a. In: Electronic resource. Mode of access to text:

$\mathrm{http}: / /$ www.information-philosophie.de/? $\mathrm{a}=1 \& \mathrm{t}=2503 \& \mathrm{n}=2 \& \mathrm{y}=5 \& \mathrm{c}=29$

Stolzenberg (2009b): Stolzenberg, J. «Geschichten des Selbstbewußtseins. Fichte - Schelling Hegel». In: Gestalten des Bewußtseins. Genealogisches Denken im Kontext Hegels. Hrsg. v. Birgit Sandkaulen, Volker Gerhardt und Walter Jaeschke. Hamburg: Meiner, 2009b, S. 2749.

Wirth (2002): Wirth, U. «Der Performanzbegriff im Spannungsfeld von Illokution, Iteration und Indexikalität». In: Performanz. Zwischen Sprachwissenschaft und Kulturwissenschaften. Hrsg. Uwe Wirth. Frankfurt: Suhrkamp, 2002, S. 9-60.

Стаття отримана редакцією 3.08.2014 


\section{Stefan Lang}

\section{Fichte's Program of a History of Performative Self-Consciousness}

In this paper Fichte's conception of a theory of consciousness and self-consciousness is examined as it is presented in the «Foundations of Natural Right» (1796/7) and in «Attempt at a New Presentation of the Wissenschaftslehre» (1797). It is argued that Fichte develops a performative interpretation of self-consciousness. The main thesis of the paper is that Fichte provides a performative theoretical program, i.e. the history of performative self-consciousness.

Stefan Lang, PhD, Research assistant, Martin-Luther-University Halle-Wittenberg

Штефан Ланг, доктор філософії, науковий співробітник, університет Мартина Лютера (Гале, Німеччина)

Штефан Ланг, доктор философии, научный сотрудник университета Мартина Лютера (Галле, Германия)

e-mail: stefan.lang@phil.uni-halle.de 